Bauer's view, but a subsequent trial in Paki$\operatorname{stan}^{6}$ failed to demonstrate a statistically significant effect. In addition Rao et al. ${ }^{7}$ in a controlled and supervised trial with a closely related compound, shown to be highly effective in the laboratory, were able to show only a minimal prophylactic effect. If the thiosemicarbazones are really as effective against variola virus in man, as Dr. Bauer claims, it is surprising that they have no appreciable effect on the success rate of vaccination with the closely related vaccinia virus. ${ }^{7}$

Until more conclusive evidence is presented in favour of hyperimmune gammaglobulin and antiviral drugs of the thiosemicarbazone series we consider that vaccination with all its limitations must remain the first line of defence in containing outbreaks of smallpox. In our view this should be combined with hyperimmune gammaglobulin for those at particular risk. At the present time we do not believe that thiosemicarbazones have a part to play in the routine prophylaxis of smallpox.-We are, etc.,

RONALD T. D. EMOND Deparement of Infectious Diseases,

Royal Free Hospital,

Department of Infectious Diseases,

St. Ann's General Hospital,

London N.15

1 Dixon, C. W., Smallpox. London, Churchill, 1962 .

2 Kempe, C. H., Berge, T. O., and England, B., Pediatrics, 1956, 18, 177

3 Kempe, C. H., et al., Bulletin of the World Health Organization, 1961, 25. 41.

4 Bauer, D. J., St. Vincent, L., Kempe, C. H., and

Downie, A. W., Lancet, 1963, $11,494$.

Do Valle, L. A.' R., De Melo. P. R., Gomec, 2. $\mathbf{9 7 6}$.

- Heiner, G. G., et al., Americ

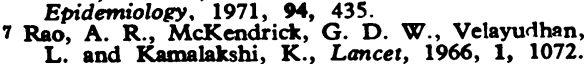

\section{Vingl Chloride and Cancer}

SIR,-I could not help feeling that your otherwise well-balanced leading article on this subject (30 March, p. 590) tended to oversimplify two problems. Reference is made to the induction of saroomas at the site of subcutaneous implantation of plastic films and it is suggested that tumour induction is dependent on the "uninterrupted area of the film" This is not universally true and the possible importance in relation to canoer induotion of chermical agents that can be leached out of plastios has not been ruled out.' Plastic sponge is potently productive of sancomas on implantation ${ }^{2}$ and fragmented polyethylene proved just as potent as a solid piece of the same material in producing sarcomas. ${ }^{3}$ Also other factors such as the relative numbers of anions and cations may be important." In any case, in the light of the work of Grasso and Golberg $^{5}$ few authorities in the field of experimental carcinogenesis would now accept the induction or non-induction of sarcomas in the subcuraneous tissues of rats in response to the subourtaneous injection or implantation of foreign materials as providing information that is indicative either of safety or hazard for man of materials to which he is not exposed by a parenteral route. On the other hand, an interpretable and usefud observation from this kind of experiment in the case of polyvinyl chloride would have been that acoustic duct tumours did or did not occur in rats bearing implants.

That there is a need for a series of simple inexpensive tests which suggest that some substances are more likely to be carcinogens than others is indisputable. Nor would one reject the view that short-term in-vitro studies may be of value in warming that substances may be carcinogens and in the elucidation of mechanisms of carcinogenicity. ${ }^{7}$ But what must be disputed is whether mutation of a micro-organism of transformation of cells in vitro should be regarded as reliable evidence of caroinogenicity. The reliability of such short-term tests for predicting carcinogenicity needs to be assessed and the false-positive and falsenegative rates ascertained. Unfortunately this can only be done laboriously by comparing the results of short- and long-term tests. Where this has been done in the past the approach has generally been to show that known, usually potent, carcinogens give positive results in short-term tests, and even this has not always proved easy. The opposite approach-namely, of seeing whether substances which give rise to weekly positive results in short-term tests or which unexpectedly give rise to positive results predispose to meoplasia in the long term-has rarely been followed.

Clearly much more thought is going to have to be used to protect workers against possible cancer hazard from new chemicals and materials used in industry, but confusion and little benefit would result from falsely labelling substances as carcinogens on the basis of short-term tests of unproven validity. Committees of experts that have review̄ed carcinogenicity testing during recent years have invariably rejected shortterm tests for the purpose of establishing safety. ${ }^{8} 9$ We should be equally careful to reject them for the purpose of establishing hazard.-I am, etc.,

London SW19

Francis J. C. ROE

1 Heuper, w. C., and Conway, w. D. Chemical Carcinogenesis and Cancers. D., Springfield, Carcinogenesis

2 Dukes, C. E., and Mitchley, B. C. V., British fournal of Plastic Surgery, 1962, 15, 225.

of Cancer, $1969,23,401$. . C., and Peto, R., fournal of the National Cancer Institute, 1971, 46, 1277.

Grasso, P., and Golberg, L., Food and Cosmetic Toxicology, 1966, 4, 297.

Gangolli, S.' D., Grasso, $\dot{P}_{\text {, }}$ and Golberg, L., The Testing of Chemicals for Carcinogenicit Mutagenicity and Teratogenicity, Department of National Health and Welfare, Ottawa, Canada, 1971.

8 World Health Organization, Principles for Testing and Evaluation of Drugs for Carcinogencity: Technical Report Series No. 426. Geneva, W.H.O., 1969.

9 Food and Drug Administration (U.S.A.) Toxicology and Applied Pharmacology, 1971, 20 ,
419.

\section{Amitriptyline and Imipramine Poisoning in Children}

SIR, - Drs. K. M. Goel and R. A. Shanks (16 February, p. 261) outline the numerous dangers of tricyclic antidepressant overdosage and sound a very timely warning on the folly of prescribing such drugs for children. I am concerned, however, that they should state that there is "no known antidote." Much more alarming is the letter from Drs. D. A. Price and R. J. Postlethwaite (23 March, p. 575) advocating the use of parenteral diphenylhydentoin in patients poisoned with these drugs. It is evident from such communications that experience in the management of tricyclic antidepressant poisoning is limited, as Drs. Price and Postlethwaite admit.

The antidote available for tricyclic antidepressant poisoning is physostigmine. It was first described by Slovis et al. ${ }^{1}$ in 1971 followed by Rumack ${ }^{2}$ in 1973. In the near future this agent will be recommended by drug companies marketing tricyclic antidepressants for use in the event of overdosage. It is important that a critical appraisal of this form of treatment should be made available.

In this centre we recently treated with physostigmine salicylare 21 consecutive patients with acute tricyclic antidepressant poisoning. In this series unoonsciousness, hyperreflexia, bilateral extensor plantar responses, and the classical peripheral anticholinergic effects were all rapidly reversed -a clear indication that phvsostigmine saliovlate is an antidote in tricyclic poisoning. On the other hand, though 409 patients with tricyclic antidepressant poisoning have been admitted to this centre during the past five years no fatalities have been encountered using the conservative supportive regimen described by Matthew and Lawson. ${ }^{3}$ Physostipmine has thus no place in the routine management of such patients. This statement is supported by the occurrence of potentially dangerous side effects associated with administration of this drug. In our series two of the 21 patients had convulsions and two others hypersalivated and developed a severe bradycardia due to cholinergic action. Despite these dangers physostigmine is of value in severely poisoned patients where other medical complications demand that the period of unconsciousness should be shortened.-I am, etc.,

RAY NEWTON

Regional Poisoning Treatment Centre, The Royal Infirmary,

1 Slovis, T. L., Ott, J. E.. Teitelbaum, D. T., and 451.

2 Rumak, B. H., Pediatrics, 1973, 52. 449.

3 Matthew, H., and Lawson. A. A. H., Treatment of Common Acute Poisonings, 2nd edn., Edinburgh, Churchill Livingstone, 1970

SIR,-The letter from Drs. K. M. Goel and R. A. Shanks (23 March. D. 575) in reply to Dr. R. N. Wilson's criticism (9 March, p. 455) unfortunatelv indicates that the authors themselves have not quite appreciated the significance of their own paper. Dr. Wilson has clearly pointed out the consequence of not distinguishing between inadventent (accidental) ingestion and deliberate, planned (therapeutic) ingestion. In fact in their original paper (16 February, p. 263) Drs. Goel and Shanks have themselves fallen into this error for they state that "children who ingest tricyclics in whatever dosage [my italics] should always be admitted for observation and continuous cardiac monitoring for 24 hours, because arrythmias in these cases are common and dangerous." By saying this they include all who are being treated for enuresis too.

Dr. Wilson says that the Daily Mirror article conveys the impression that the therapeutic dose was to blame. How oould the Daily Mirror be blamed if the authors did not make the distinction between thera- 